\title{
CONTEMPORARY AESTHETICIAN AS A THERAPIST OF A SENSE RATIO DISORDER
}

\section{A B S T R A C T}

The first part of this paper provides background and motivation for McLuhan's concept of alienation as a consequence of modern visual culture. Since this culture has been predominantly produced by means of traditional media, and not by economical organisation of production, the insight in media structures uncovers the very existence of certain sense ratio's disproportion. Bearing that the linear world of writing should take on responsibility for a sense ratio disorder, the author analyses McLuhan's suggestion that the turn towards new electronic media implies the current changes with which the new media are destroying the old selfhood. After questioning the reasons for utterly optimistic expectations of new audiovisual media to provide the key support for the establishing of the genuine, balanced and fair-minded human, the author points out the suitability of the idea about the creation of new media self-awareness thanks to the aesthetical contributions in studying of new approaches to various models of sensitiveness. In conclusion, the author claims that an aesthetician is then no longer just an expert for artistic transcendence, but also a therapist of the threatened equilibrium among the senses. 
The starting point of all dystopia interpretation is the perception that it is not readable as a dark prognosis of a malignant political propaganda which with the help of the new media is destroying spirituality and humanness, but is more of a resigned farewell of a literary world in demise. Because of that, the avant-garde hail to the faithfulness to their own time will remain worthy for McLuhan as well: "Today we start to take into account that the new media are not just mechanical toys whose quality is to generate a world of illusion, since they are creating a new language of an unspeakable expressive power." The distinctiveness of that calling also includes the tendency to attribute alienating proneness, if there is any point mentioning it, to the past which is best left behind. If the today's media are not creating the world of illusion, as McLuhan's opponents are claiming, the question arises if they ever did? In other words, was it ever appropriate to accuse the media for alienation?

The idiom of incomparability does not emerge accidentally in McLuhan's defence of the new media. Their "underground" activity is consisted in the configuration of newly appropriate expressions which implies the reconfiguration of the mutual balance of forces between human senses. A similar role was held by the media in the past; however that always resulted in a shifted constellation. In the background of the view that the new media is incomparable, hides the warning that we cannot interpret them with the criteria we have inherited from the old media. If we generalise that warning, we could come to the conclusion that it is pointless to connect the media with the idea of man's alienation. In every age there was a dominance of certain media, which was then followed by the age of the new media, followed by noisy protest of the old media for being given a subordinate role. In that aspect, McLuhan's historicism is unrelenting.

That means that it is inevitably wrong to mourn because of the current changes in which the new media are destroying the old selfhood, since it is exactly that selfhood that we must dismiss in order to be levelled with our own historical moment. The most unacceptable conscious content of an avant-garde theoretic of media should be denounced as an inert presence of an outlived form of consciousness which was created by once dominant media: "Our most impressive words and thoughts betray us by referring to the previously existent, not to the present." ${ }^{2}$

Self-consciousness for McLuhan implies understanding of the media forms of our awareness. If so, then we have no reason to give more advantage to some historical characters of the spirit then others, since they are all equally brought to the surface via the dominant media. If we accept that there is no point in accusing the media for the construction of the foreign, then it is the media 
orientated search for the relationship of freedom and alienation doomed from the start, and the meaning of alienation is reduced to the inability of the inert forms of media consciousness to manage in the new circumstances. However, when we move further away from this base level, and pay more attention to McLuhan's actual interpretations of creation ages of media history, we will come to different conclusions.

The differentia specifica of the media channelling of our senses is in the constitutions of a certain ratio, that is, a disproportion between sense ratios:

But the price we pay for the special technological tools $[\ldots]$ is that these massive extensions of sense constitute closed systems. Our private senses are not closed systems but endlessly translated into each other in that experience which we call consciousness [...] Our technologies, like our private senses, now demand an interplay and ratio that makes rational co-existence possible. ${ }^{3}$

The difference between the open and closed, natural and artificial was made with the intent to examine the effect, and not the meaning. The key orientation in that examination is more leaned to the insight that our senses do not have a timeless structure which is able to expand its limitation with media accessories. On the contrary, the artificial and close character of the media extension testifies of the fact that media simply contribute to the sense ratio disharmony. Some media favour some senses on account of others, which directly affects human self-understanding. Because of that, the reciprocity of sense recommended itself as a reliable means of overcoming the inherited estrangement.

In accordance to this, the modern age is for McLuhan transfused with the spirit of Gutenberg's discovery. The modern man is a typographic man, and his distinctiveness is in the domination of the eye upon other senses. Unlike the synthetic sense of hearing which dominated the tribal world, the eye is neutral and cold, so it enables a distanced reflection and individuation, but also gives the opportunity for suppressing emotions in communication. McLuhan is convinced that, if on the basis of sense ratios we ask a question on the media construction of the foreign, we would again be led to the astounding answer that the modern man is alienated to an extreme. The epoch which covered itself in the ideas of freedom and enlightenment, has in fact been based on the media intensification of alienation. Condemning a man to continuous visualisation and to the segregation of emotional contents from the awareness of the material world, the typographic human found the ideal type in Descartes' solitary meditating individual. His relationship with the community is primarily 
asocial, while his freedom seeks self-isolation over association and true social interaction. Often, it is established for the sake of preservation of a unique achievement of the typographic age: points of self-reflection, around which two major modern formations are constituted: egoism and nationalism.

Unlike the former global participation which consisted of a turbulent vicissitude between action and reaction, the civil community has constituted itself upon assimilation and decency: "The typographic logic created the outsider, the alienated man ..." By placing the visual sphere in the front row, Gutenberg's discovery only worsened the conflict of the heart and the mind, so the culprits for the confrontation between the sense and the spiritual should no longer be searched for only in Platonism or Christianity, but also in the alienated consciousness whose communication with the others is mostly based on a distant encounter with the printed media: letters, books, magazines. Centurylong age of reign of visualisation is also the age of the submission of other sense. If the commonly quoted analogue by which the modern man is a visual Narcissus can be found appropriate, then its meaning should no longer be connected with the satirical pose of power of the self-enamoured hyper-egoism, but to a diagnosis of numbness, to a consequence of the cultivation of specified sensations. McLuhan's neurological prefix for the theory of media states that the numbness of the nervous system irrefutably represents his answer for the bombardment of a single sense.

Narrations which warn of the danger of mass alienation, upon which the machinery of dehumanisation is powered by the inhumane structure of capitalism, or simply insularity of broniration of every "ism", get some unexpected competition in that manner - the visual world. The faith in its noble effects oversaw the possibility of a reaction. An expert of visualisation is not a person who managed to make the closest possible connection to the world, ${ }^{5}$ but only the first to successfully stand the narcosis. Undoubtedly, we would rightfully refuse to equalise the state caused by unemployment or the inhumane treatment, with the role on the workplace with the deformations of consciousness caused by the systematic suppression of the non-visual sphere. However, it is equally true that experience has taught us with different forms of alienations that it becomes most prominent in those places where it is not even seen at first. If we add to that the claims of the end of the literary world which were coming formal around, then the enormous interest for McLuhan's opinions can be recognised in their optimism. Unlike the dystopian protest for the sake of preservation of humanity embodied in the printed media, for McLuhan, the news of the end of Guttenberg's reign is regarded as a blessing. 
McLuhan's understanding of the modern man as alienated implies that the shift from the visual to the languages of other sense in the Gutenberg's era was not conducted properly. Although his theory of media is based on the assumption that "the definition of the dominant media includes the fact that is inevitable", the dominance of the leading media does not necessarily mean dictatorship. Based on the fact that rationality for him is equal to the harmonised senses, the sense ratio which does not exist by itself since the time of the tribal man, the response to the challenges of the media is not in a resigned protest, but in the display of models upon which the corrupted balance can be restored. If in the attempt to find the appropriate model, we turn for help to modern phenomenology and neurology, we will come to the new formulations of an old insight:

Reflection and acceptance thus form a double fold of cognition and affection, dynamically recovering one another in linking one to another, to the point that cognitive reflection and affective openness cease to be opposed to one another in the process of becoming aware, but form a non-duality. ${ }^{7}$

A close connection between affection on which the contemporary author insists is simply an echo of a familiar request for unique spontaneity and receptiveness in which there will be no place left for hierarchy, for an expressed dominance of the reflexive over the senses. That what had a provocative burst with Nietzsche, directed against the dominance of the spirit against the senses, in the thesis of the great mind of the body, has become almost self-understandable to the modern thought. However, the kinship of Nietzsche's thinking with his philosophical predecessors is in the assumption that there is a unity of the sense, in a firm interaction and complementarities between certain senses. It implies that between certain senses, a productive cooperation has already been established, which gives Kant the right to speak in singular of the sense diversity, and Hegel of sense spontaneity, and not being forced to specify what sense they are relating to. Even more, Merleau-Ponty will say that the cineaste perception is no exception, but a rule of the transversal character of our sense: "Senses are translated into each other without the need of a translator."

Unlike the philosopher, McLuhan insisted on the opinion that the unity of sense in the modern world is fictional. The sense ratios always assume the media created imbalance among senses. An aesthetician is then no longer just an expert in artistic transcendence, but also a therapist of the senses, ready to favour creation perceptive codes which will compensate the repressed sense experiences and in that way contribute to the establishment of a true unique 
sense. Being that the $20^{\text {th }}$ century aesthetics managed to cast away the hierarchy of the spirit and the senses, the only thing it was left with was to technically cancel out the existing hierarchy between the senses themselves. The end of that hierarchy will mark the end of the media production of alienation.

McLuhan's "media optimism" is based on the belief that after Gutenberg's age came Marconi's age, which meant that the sight was no longer dominant. If we admit the deficiencies of Guttenberg's age, the whole term of audio-visual will speak on behalf of the new media's capacity to contribute to the establishment of the disturbed balance. The profound experiences, the revival of the lost senses and the recovery of the power of imagination and fantasy have been pointed out as a valuable arsenal of effect of television. Unlike Enzensberger, who will recognise the zero medium in television, the "Buddhist machine" on which a man plugs himself in order to "unplug himself" the apparatus of the magical effect whose function is reduced to the encouragement of the self-loss and selfoblivion, a voluntary exile into the void, McLuhan will in its effects recognise the renaissance of the integral awareness. After the distanced homogeneity of the writing, comes the era of intensive participation, a more direct relationship with the world, in which discontinuity and heterogeneity are dominant. McLuhan's understanding of the television media implies the realisation of a lifelong dream of the avant-garde on the breakdown of the distance that divides us form the profound experience of reality, on "the absence of the control by the mind" 10 . Moreover, the television performs a remarkable educational function, which is not related to the broadcast educational shows, but to the school of spontaneity, for the practice of "total involvement":

It is the total involvement in all-inclusive nowness that occurs in young lives via TV's mosaic image. This change of attitude has nothing to do with programming in any way, and would be the same if the programmes consisted entirely of the highest cultural content. ${ }^{11}$

Five decades after the publications of McLuhan's works, we are the witnesses of a vast list of literature which presents the enormous capacities of television, but also other audiovisual media to generate alienation. McLuhan's promise of an integral presence, but also new sociality, is most commonly deformed in a disintegrated absence, into a new asocial whose distinctiveness consists of a lonesome consummation of cultural contents. Participation in the present is reduced to its simulation in the comfort of your home, which you needn't leave anymore to watch a film or listen to a concert, which inevitably includes concept with other human beings: "The message of the medium has become the message of the incapacity of an individual." ${ }^{\prime 2}$ 
The culture of doubt in honesty and truthfulness of the media contents has in the meantime become a self-implicit characteristic of education. Dystopian mood of the contemporary viewer has been impregnated with doubt, since the modern sensibility, stripped of the trust in the future, does not wish to sacrifice its present on the altar of "global information". The ongoing conflict between the printed and electronic media has not yet been decided, although we are witnesses of the penetration of books and newspaper in the areas where McLuhan would not expect them. The cross of the mosaic and linear in books and magazines distributed by internet signalises the possibilities of reconciliation between Guttenberg's and Marconi's worlds. Apart from that, with an accent on integral, simultaneous time, we can still not explain the fact that History Channel remains one of the most popular programs on air. Even more confusing is why the everyday confrontation with the new media messages is reduced to the desperate protest of the elite culture, whose contest are being placed in the worst possible air-times. However, the question is how much we would even pay attention to these questions if not for the contradictory, but very lucid observations made by McLuhan. In them, particularly actual are those on media control, the necessity to base the inherited reason of critic not only on academic, literary argumentation but also on other models. In other words, McLuhan was right when he claimed that the limits of our social reaction on media are appropriate only in regards to the press, since we are not able to immanently approach the new media and do not have direct access to their messages. In that aspect, his views coincide with Waldenfels: "Different view does not match different descriptions to different interpretations." 13

However, to gain a different view we firstly must cast aside the superficial opposites which McLuhan was so fond of: visual vs. organic, organic vs. mechanical, individual vs. tribe - and never lose out of sight that man's relation to the world can always be indirect, even when he is experiencing it in indirect way $^{14}$ - and then we can rightfully expect the future to bring productive steps towards the realisation of the idea to of the necessity of "protection from media showers". When successful, media analysis is nothing more than a form of normalisation ${ }^{15}$, social support against new forms of media initiated poverty.

Unless we ask the very actual question on the responsibility of the contemporary aestheticians, we approach the point in which McLuhan's observations on media control contact the opinions of his opponents. Regardless of the different propositions on the man of the future, they equally represent the argument of the responsibility of the contemporary aestheticians in the way that he is supposed to lessen the negative effects of the media and to assert the positive ones. In McLuhan's' poeticised version that argument appears like this: "The artist is 
the historian of the future because he uses the unnoticed possibilities of the present." ${ }^{\prime \prime}$ Pointing out the unmarked possibilities is welcome by itself, and will be equally warmly greeted, regardless of whether it's a futuristically, avantgarde theoretician of media, or a dystopian critic of media whose culture is trying to protect us from the traps of the past.

When discussing what both theories have overlooked, what catches the eye is their tendency towards theme of alienation in the negative sense of the word, neglecting the question of the affirmative estrangement, media affiliated transformation of selfhood in the direction of humanisation, and not alienation. If we could pay more attention towards that kind of strategy, the future models of media control would have more chance to succeed. This is especially the case when they manage to outmatch the existing arguments on the untouchability of the self via dynamically structured experience which enriches the individual, pointing him to the new experience possibilities. With that, a more intensive degree of cooperation with aesthetics is recommended, in a degree even higher than the one McLuhan originally suggested, regardless of the fact that that cooperation risks "referral to what already existed". Structures of alienation are something "old", with what we can't manage by simply turning towards the new. Paris: présénte par G. E. Stearn, 1969), 102.

It is interesting that a thinker such as Jacques Attali recently reached for an argument typical for McLuhan's understanding of media: "For twenty-five centuries, Western knowledge has tried to look upon the world. It has failed to understand that the world is not for the beholding. It is for hearing. It is not legible, but audible." Jacques Attali, Noise. The Political Economy of Music, trans. B. Missumi (Minneapolis / London: Minnesota University Press, 2009), 3. 
Maurice Merleau-Ponty, Phénoménologie de la perception (Paris: Gallimard, 1945), 271.

Hans Magnus Encensberger, Ogledi, trans. Z. Krasni, (Novi Sad: Svetovi, 1994), 85. André Breton, Manifestes du surréalisme (Paris: Gallimard, 1963), 37.

Marshall McLuhan, Understanding Media, The Extensions of Man (Cambridge, Mass. / London: MIT Press, 1998), 335.

Boris Groys, Unter Verdacht. Eine Phänomenologie der Medien (München: C. Hanser, 2000), 98.

Bernhard Waldenfels, Sinnesschwellen. Studien zur Phänomenologie des Fremden 3 (Frankfurt a/M: Suhrkamp, 1999), 153-154.

It is not a coincidence that Plessner's second anthropological law is titled in Hegel's spirit, the law of mediated spontaniousness.

Bernhard Waldenfels, Philosophisches Tagebuch. Aus der Werkstatt des Denkens 1980-2005 (München: W. Fink, 2008), 2008. 
Attali, Jacques. Noise. The Political Economy of Music. Translated by B. Missumi. Minneapolis/ London: Minnesota University Press, 2009.

Breton, André. Manifestes du surréalisme. Paris: Gallimard, 1963.

Depraz, N., Varela, F., Vermersch, P. On Becoming Aware: a pragmatics of experiencing. Amsterdam / Philadelphia: John Benjamins Publishing Company, 2003.

Enzensberger, Hans Magnus. Ogledi. Translated by Z. Krasni. Novi Sad: Svetovi, 1994.

Groys, Boris. Unter Verdacht. Eine Phänomenologie der Medien. München: C. Hanser, 2000.

McLuhan, Marshall. The Gutenberg Galaxy, The Making of Typographic Man. London: Routledge \& Kegan Paul, 1962.

McLuhan, Marshall. Verbi-Voco-Visual Explorations. New York / Frankfurt / Villefranche-surmer: Something Else Press, 1967.

McLuhan, Marshall. "Nous commençons aujourd'hui..." In Pour ou contre McLuhan, présénte par G. E. Stearn. Paris: Seuil, 1969.

McLuhan, Marshall. Understanding Media, The Extensions of Man. Cambridge, Mass. / London: MIT Press, 1998.

Merleau-Ponty, Maurice. Phénoménologie de la perception. Paris: Gallimard, 1945.

Waldenfels, Bernhard. Sinnesschwellen. Studien zur Phänomenologie des Fremden 3. Frankfurt a/M.: Suhrkamp, 1999.

Waldenfels, Bernhard. Philosophisches Tagebuch. Aus der Werkstatt des Denkens 1980-2005. München: W. Fink, 2008. 


\section{SAVREMENI ESTETIČAR KAO TERAPEUT NESRAZMERE MEĐU ČULIMA Dragan Prole}

Prvo deo članka izlaže pozadinu i motivaciju Makluanovog pojma otuđenja kao posledicu moderne vizuelne kulture. Budući da je ta kultura prevashodno proizvedena posredstvom tradicionalnih medija, a ne putem ekonomskih organizacija, uvid u strukturu medija otkriva postojanje izvesne nesrazmere među čulima. Imajući u vidu da je za tu nesrazmeru odgovoran linearni svet pisma, autor analizira Makluanovu sugestiju da okret prema novim elektronskim medijima implicira savremene promene u kojima će novi mediji destruirati staro sopstvo. Nakon razmatranja razloga za krajnje optimistična očekivanja od novih audio-vizuelnih medija u pružanju podrške za uspostavljanje izvornog, balansiranog i uravnoteženog čoveka, autor razmatra održivost ideje o stvaranju nove medijske samosvesti zahvaljujući doprinosima studiranja novih pristupa različitim modelima čulnosti. U zaključku autor naglašava da estetičar onda nije ekspert za umetničku transcendenciju, nego terapeut ugrožene ravnoteže među čulima.

KLJUČNE REČI: MAKLUAN, AVANGARDE, OTUĐENJE, ČULNA SRAZMERA, CELOKUPNI ČOVEK

\section{DISCIPLINSKA KRIZA U VREDNOVANJU UMETNOSTI \\ Nataša Lah}

Uopšteno govoreći, vrednost među objektima - kao i među umetničkim vrednostima - definišu se na osnovu posebno značajnih odlika i uslova koji razlikuju npr. privilegovanje tog umetničkog dela u okviru porodice srodnih pojava i predmeta; prvo u vreme nastanka, a onda i u sadašnjem vremenu. Istorija estetike i kulture odražavaju nestabilan status uslova koji određuju umetničke vrednosti, tj. uslova za istorijsku promenu vrednovanja. Predmeti ili pojave koji tokom istorije pretenduju da budu ono što danas nazivamo vrednim umetničkim delima, stekli su neophodne kvalifikacije u okviru hijerarhijskog okvira kulturne potražnje njihovog vremena. Dinamičan sistem promena ujednačavanja vrednosti umetničkih dela sa njihovim društvenim statusom doveo je do disciplinarne krize teorije umetnosti koja nije uspela da se prilagodi aksiološki novim načinima prijema umetnosti, ni savremenim standardima. U tom smislu, daću kratak prikaz krize sa stanovišta osnovnih pitanja u vezi značenja lepote, vrednosti i vrednovanja u okviru kulture i umetnosti tokom istorije. Lociraću fokus ove krize u okviru perioda od šesnaestog do osamnaestog veka (bez romantizma) kada je istorija umetnosti postala jasno izražena disciplina, uključujući mehanizme vrednovanja tog perioda u svoju posebnu metodološku matricu, kao da je ona vanvremenska i neistorijska.

KLJUČNE REČI: AKSIOLOGIJA UMETNOSTI, ISTORIJSKE PARADIGME VREDNOVANJA, AKSIOLOŠKA MATRICA ISTORIJE UMETNOSTI, KULTURNO PRIHVATANJE VREDNOSTI

POSTMODERNIZAM I POST-SOCIJALISTIČKI USLOV:

15 GODINA KASNIJE (2003-2018)

\section{Aleš Erjavec}

Autor daje kratak rezime koncepta ,post-socijalističkog“ili avangardnog pokreta „,treće generacije“. On objašnjava istorijske i političke uslove koji su omogućili pojavljivanje ove specifične avangardne umetnosti. Po njegovom mišljenju, jedinstvena vrsta umetnosti se pojavila u socijalističkim zemljama tokom raspada socijalizma sovjetskog tipa usled sličnih okolnosti. Kada su se globalni i lokalni politički uslovi promenili, ova umetnost je uglavnom nestala, ostavljajući za sobom samo tragove svog postojanja. Autor ističe specifične likovne mehanizme korišćene u ovakvoj umetnosti i tvrdi da je treba priznati kao još jednu vrstu avangardne umetnosti dvadesetog veka. 